\title{
Analysis of Rainfall Dynamics in Conakry, Republic of Guinea
}

\section{Ibrahima Kalil Kante 1,2,3, Saïdou Moustapha Sall1, Daouda Badiane1, Ibrahima Diouf 1,4, Abdoul Lahat Dieng ${ }^{1}$, Idrissa Diaby ${ }^{3}$, Françoise Guichard ${ }^{5}$}

\author{
${ }^{1}$ Laboratoire de Physique de l'Atmosphère et de l'Océan Siméon Fongang, École Supérieure Polytechnique, Université Cheikh \\ Anta Diop, Dakar, Senegal \\ ${ }^{2}$ Direction Nationale de la Météorologie de Guinée, Conakry, Guinea \\ ${ }^{3}$ Laboratoire d'Enseignement et de Recherche en Énergétique Appliquée, Université Gamal Abdel Nasser de Conakry, \\ Conakry, Guinea \\ ${ }^{4}$ NOAA Center for Weather and Climate Prediction, College Park, USA \\ ${ }^{5}$ CNRM-GAME (CNRS and Météo-France), Toulouse Cedex, France
}

Email: ibrahima.kante@ucad.edu.sn

How to cite this paper: Kante, I.K., Sall, S.M., Badiane, D., Diouf, I., Dieng, A.L., Diaby, I. and Guichard, F. (2020) Analysis of Rainfall Dynamics in Conakry, Republic of Guinea. Atmospheric and Climate Sciences, 10, 1-20.

https://doi.org/10.4236/acs.2020.101001

Received: September 17, 2019

Accepted: November 22, 2019

Published: November 25, 2019

Copyright $\odot 2020$ by author(s) and Scientific Research Publishing Inc. This work is licensed under the Creative Commons Attribution International License (CC BY 4.0).

http://creativecommons.org/licenses/by/4.0/

(c) (i) Open Access

\begin{abstract}
Observed rainfall data of the National Meteorological Service of Guinea (NMS) exhibit that synoptic station usually records the largest rainfall amount in Guinea. Only few studies have been done on this rainfall peak observed in Conakry. This work better analyses the atmospheric dynamics leading to rainfall particularity. Using NMS data from 1981 to 2010, the monthly contribution and mean seasonal cycle of each station has been done. These findings of the study show that between July and August (rainfall season peak), the coastline particularly Conakry records the largest amount of rainfall. Using Era Interim data for the common period (1981-2010), we also investigate the rainfall dynamics in the lower level $(1000 \mathrm{hPa}-850 \mathrm{hPa})$ from precipitable water, divergence, and moisture flow transport. There is a west and southwest moisture flow transport explained by a strong moisture convergence in the coastal region (Lower-Guinea). Furthermore, values of precipitable water in the same region are found, in agreement with the high moisture flow transport gradient. These incoming flow (west and south-west) undergo a return by blocking's Kakoulima range (foehn effect) and Fouta Djallon massif to initiate convection clouds on the Guinean coast. These processes enhance a convergence of moisture associated with orographic origin convection. This has an important effect by increasing the rainfall amount in Conakry.
\end{abstract}

\section{Keywords}

Conakry, Guinea, Maximum Rainfall, Precipitable Water, Divergence, 


\section{Introduction}

In West Africa, deep convection exhibits important variability by convective mesoscale systems (squall lines), but also by local thunderstorms or smaller convective systems [1]. It is often associated with East African Waves [2]. The tropical convective clouds often evolve into organized clusters with anvils blending in a single mesoscale cloud [3]. They have a fundamental importance for the earth's climate especially for its radiative energy balance [4]. Its triggering also depends of surface heat flow and soil moisture [5] [6]. The temporal evolution of these sensible and latent heat flows is strongly marked by precipitating elements. Mesoscale convective systems and squall lines are the most commonly observed rainfall systems in Sudano Sahelian belt [7] [8]. Thus, rainfall comes largely from water vapor condensation in the atmosphere [9].

\subsection{West Africa Rainfall}

The tropical Africa rainfall and Atlantic during the West African Monsoon come from convective systems with a wide range of proprieties (stormy, squall lines). Indeed, studies conducted by [10]; shows that in West Africa, there are two bimodal rainfall peaks in: the region including Guinean, Liberian, Sierra Leonean so-called the Roberts FIR (Flight Information Region) and the region in Gulf of Guinea. Figure 1 illustrates the rainfall in West Africa with the Climatic Research Unit data (CRU) during the period 1951-2002.

\subsection{West Africa Orography}

Looking at a map of Africa's current topography, two areas of high and low

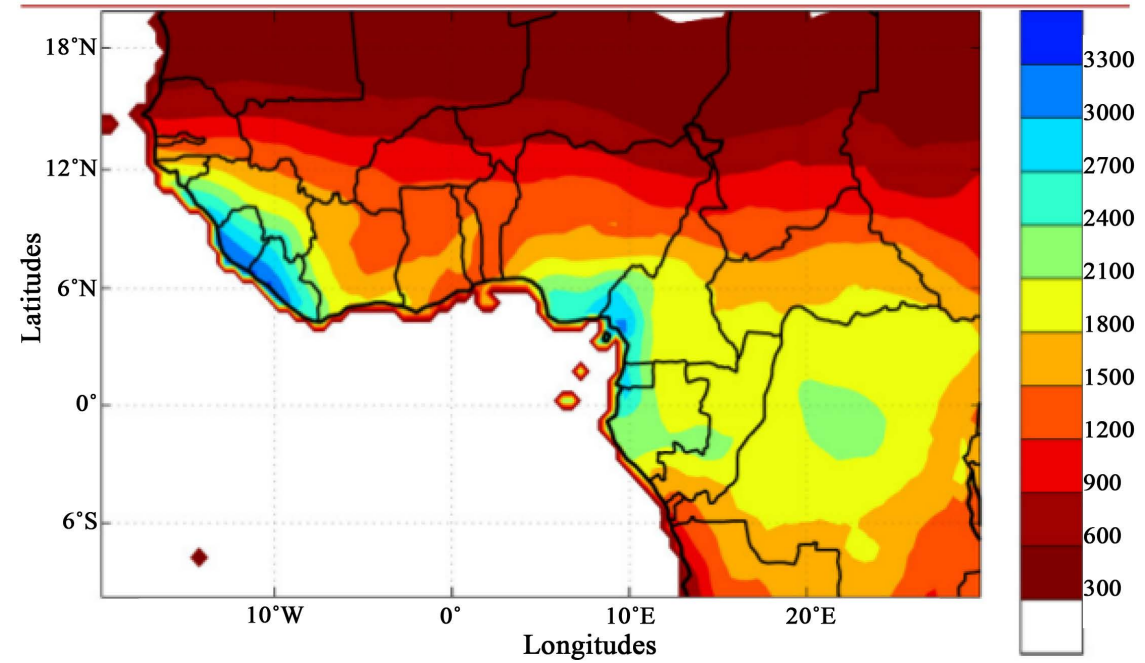

Figure 1. Annual rainfall average in West Africa from $12^{\circ} \mathrm{S}-20^{\circ} \mathrm{N}$ to $20^{\circ} \mathrm{W}-30^{\circ} \mathrm{E}$ (CRU, 1951-2002) [10]. 
elevation are apparent [11]. The West African region is one of the African's areas where very high elevation is found. The West Africa is generally characterized by a fairly simple relief, consisting of vast plains, trays low altitude $(200 \mathrm{~m}$ on average) and mountains [12]. The plains occupy littoral border over Senegal and Gambia, while inside the continent, lowlands are dominant. Among the most important mountain ranges, there are the Fouta Djallo mountains in the South-West. Mount Loura, highest point of $1532 \mathrm{~m}$ and Mount Nimba, highest point of $1752 \mathrm{~m}$ [12]. In the South-East, there are the Adamaouna massif, Mountain Cameroon highest point of $4100 \mathrm{~m}$. In the North-East, there are Hoggar and Tibesti with highest point of 2900 and $3400 \mathrm{~m}$ respectively. Indeed, West Africa topography is not the only aspect of the atmospheric circulation associated with the West African Monsoon as in Asia, it plays a crucial role at regional and local scales [12]. The West Africa topography (Figure 2), shows that these two regions with two bimodal rainfall peaks correspond to the coastal orographic area under the oceanic influence. This is consistent with the results of Sall et al., 1999 [13]; and Mathon and Laurent, 2001 [14] which showed that in Africa, the main mountainous areas generally correspond to the cloud cover maximum. In this work, we focus on Guinean area (Republic of Guinea) located between $6^{\circ} \mathrm{N}-13^{\circ} \mathrm{N}$ latitude and $15^{\circ} \mathrm{W}-7^{\circ} \mathrm{W}$ longitude.

\section{Area of Study}

The area of study is shown in Figure 3, it is located between the latitudes $7^{\circ} \mathrm{N}$ $13^{\circ} \mathrm{N}$, and the longitudes $15^{\circ} \mathrm{W}-7^{\circ} \mathrm{W}$. The Republic of Guinea is a West African country, with an estimated area of $245,857 \mathrm{~km}^{2}$. It is subdivided into four (4) geophysical regions: the Lower-Guinea (LG, hereafter), the Middle Guinea (MG, hereafter), the Upper-Guinea (UG, hereafter) and the Forest-Guinea (FG, hereafter). Each geophysical region has three (3) synoptic weather stations. The naming of the geophysical regions is in accordance with their climate and topography [15].

The LG includes the synoptic weather stations of Boke, Conakry and Kindia, it is also called Maritime-Guinea due to its coastal position. It is the coastal belt

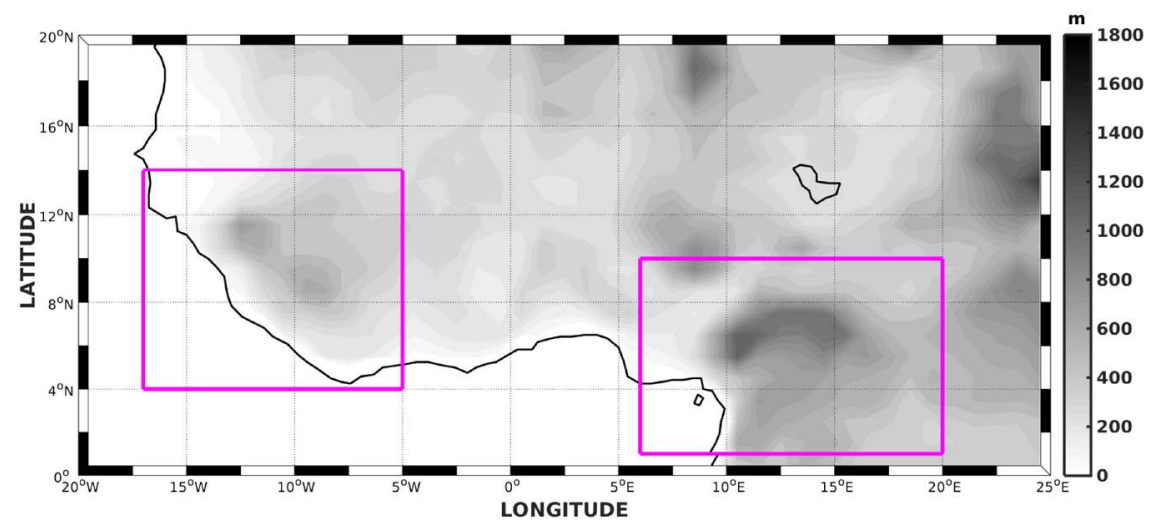

Figure 2. West Africa topography showing the orographic areas delineated in magenta. 


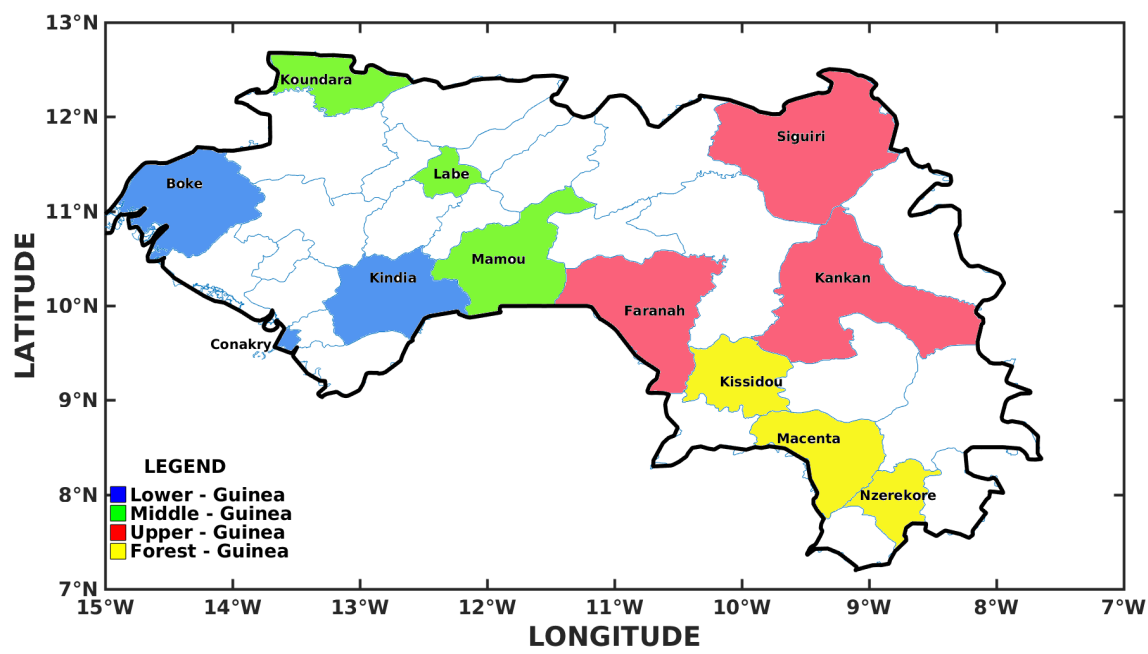

Figure 3. Synoptic stations of Guinea with its four (4) geophysical regions: Lower-Guinea (Boke, Conakry, Kindia), Middle-Guinea (Koundara, Labe, Mamou), Upper-Guinea (Faranah, Kankan, Siguiri) and Forest-Guinea (Kissidou, Nzerekore, Macenta).

between Guinea-Bissau in the north and Sierra Leone in the south (around 300 $\mathrm{km}$ ), about 100 to $150 \mathrm{~km}$ wide. It covers around $15 \%$ of the country's total area. The marine marshes occupy around 360,000 ha, including 260,000 ha of mangroves, the largest in West Africa [16]. It has a wet tropical climate, with a rainfall reaching its maximum in August and can exceed $4000 \mathrm{~mm} /$ year in Conakry [15].

The MG region includes the synoptic stations of Koundara, Labe and Mamou. It covers around $26 \%$ of the country's total area [16]. Fouta Djallon massif occupy around $80,000 \mathrm{~km}^{2}$ around and its highest point is Mount Loura (1532 m), including the most mountainous region of Guinea. Its soil consists mainly of stepped uplands over $1000 \mathrm{~m}$ wave by valleys, dominating plains and depressions with an altitude exceeding 750 and can exceed $1200 \mathrm{~m}$ in some places [15]. It is in this region where many rivers and streams of West Africa take their sources: Senegal and Gambia rivers in the north, Koliba, Rio Grande, Fatala and Konkoure rivers in the west. The Kaba rivers, Kolente to the south, and Niger to the east. Its climate is marked by a relatively high daytime thermal amplitude of up to $19^{\circ} \mathrm{C}$ in Labe [16]. The rainy season can range from five (5) to eight months between Koundara and Mamou with an amount rainfall less than 1300 $\mathrm{mm}$ to the north [15].

The UG region includes the synoptic stations of Faranah, Kankan and Siguiri covers about $39 \%$ of country's total area. It is located between Guinea-Forest and Fouta Djallon on the western edge of the Niger's vast basin. This region, with an average altitude of $500 \mathrm{~m}$, has a slight relief which explains the rivers spreading [16]. It has a Sudanese climate with annual rainfall ranging between $1600 \mathrm{~mm}$ in the south and $1200 \mathrm{~mm}$ in the north [15]. It represents the arid and Sahelian area of Guinea due to the similarity of Sahelian climate. Its grassy savanna with plateaus and river plains (River Milo) is favorable for agriculture. Temperatures 
can vary from $14^{\circ} \mathrm{C}$ during the rainy season to $37^{\circ} \mathrm{C}$ during the dry season.

The FG region includes the synoptic weather stations of Kissidou, Macenta and Nzerekore. This region corresponds to the southern part of Guinea and covers $20 \%$ of the area total of country. Its relief presents two mountains namely the Mount Simandou and Mount Nimba (highest point of $1752 \mathrm{~m}$ ). The Mount Nimba Strict Nature Reserve is a UNESCO World Heritage Site and covers most of the ecotope, where more than 200 endemic species. Duikers, lions and leopards, civets, and two species of viviparous amphibians etc. can be found [16]. This region also has a climate characterized by a long rainy season (between 7 to 9 months) [15]. More than 1300 species of plants and more than 500 species animals can be found in the Ziama Massif Biosphere Reserve [16].

The meteorological observation data and Monthly Climatological Tables of Guinea show that Conakry rainfall varies on average between 3300 and 4000 $\mathrm{mm}$ /year or more. Some authors are interested in this maximum rainfall such as Sall et al., (2007) [17] and Beavogui et al., (2011) [18] who explained it by attributing this maximum to orographic effect due to the existence of Kakoulima mountain $(1007 \mathrm{~m})$ located in $50 \mathrm{~km}$ in the east of Conakry. In addition Jenkins et al., (2008) [19] indicated a vortex presence over the Guinean coast almost stationary creating a return of rainfall systems in Conakry. In these previous studies, rainfall dynamics in Guinea were not discussed to better analyze this maximum rainfall in Conakry hence the interest of this work. The main objective of this study is to analyze the rainfall regime dynamics of Guinea and the maximum rainfall origin recorded in Conakry.

\section{Data and Methods}

\subsection{Data}

The recorded observation data by the National Meteorological Service of Guinea, Climatic Research Unit Data (CRU) and re-analysis Era Interim data are used.

\subsubsection{Observation Data}

Guinea's meteorological observation network has a very low density due to obsolete meteorological logistics and lack of performing weather observers [15]. Many of these stations (radio-sounding, synoptic, pluviometric and agronomic) have several data gaps, which sometimes complicate the use of these data. For this purpose, twelve (12) synoptic stations (Figure 3) are selected for this study in which observation network is regular, and its data are trustworthy [15]. In this purpose, we have considered 30-years climatological series recommended by World Meteorology Organization (WMO), which are the monthly cumulative data. These are monthly rainfall data for the common period from 1981 to 2010 (Table 1).

Using these observations data (rainfall), we calculate the mean seasonal cycle of rainfall and monthly contributions of each geophysical region. This study 
Table 1. Summary of available observation data.

\begin{tabular}{ccccccc}
\hline \multirow{2}{*}{ Stations } & & $\begin{array}{c}\text { Latitudes } \\
(\text { Nord })\end{array}$ & $\begin{array}{c}\text { Longitudes } \\
(\text { West })\end{array}$ & $\begin{array}{c}\text { Altitudes } \\
(\mathrm{m})\end{array}$ & $\begin{array}{c}\text { Parameters } \\
(\text { monthly) }\end{array}$ & $\begin{array}{c}\text { Time } \\
\text { period }\end{array}$ \\
\hline \multirow{5}{*}{ Lower-Guinea } & Boké & $10^{\circ} 56$ & $-14^{\circ} 18$ & 69 & Rainfall & $1981-2010$ \\
& Conakry & $09^{\circ} 64$ & $-13^{\circ} 58$ & 46 & Rainfall & $1981-2010$ \\
& Kindia & $10^{\circ} 04$ & $-12^{\circ} 86$ & 458 & Rainfall & $1981-2010$ \\
Middle-Guinea & Koundara & $12^{\circ} 34$ & $-13^{\circ} 31$ & 90 & Rainfall & $1981-2010$ \\
& Labé & $11^{\circ} 19$ & $-12^{\circ} 29$ & 1050 & Rainfall & $1981-2010$ \\
& Mamou & $10^{\circ} 38$ & $-10^{\circ} 08$ & 782 & Rainfall & $1981-2010$ \\
& Faranah & $10^{\circ} 26$ & $-10^{\circ} 80$ & 358 & Rainfall & $1981-2010$ \\
& Kankan & $10^{\circ} 12$ & $-9^{\circ} 55$ & 376 & Rainfall & $1981-2010$ \\
& Siguiri & $11^{\circ} 74$ & $-9^{\circ} 37$ & 361 & Rainfall & $1981-2010$ \\
& Kissidou & $09^{\circ} 19$ & $-10^{\circ} 11$ & 524 & Rainfall & $1981-2010$ \\
& Macenta & $08^{\circ} 32$ & $-9^{\circ} 28$ & 542 & Rainfall & $1981-2010$ \\
& Nzerekore & $07^{\circ} 75$ & $-8^{\circ} 83$ & 467 & Rainfall & $1981-2010$ \\
\hline
\end{tabular}

compares stations within the same region order to exhibit the one with largest amount of rainfall to overall in Guinea.

\subsubsection{Climatic Research Unit Data (CRU)}

Except our observation data, CRU data from 1981-2010 showed the climatological distribution of rainfall over West Africa. The CRU is a research unit from the University of East Anglia in England, which studies natural and anthropogenic climate change. These data archived in monthly period 1901-2002 are different sources of stations data following interpolation methods and homogenization, where the missing data are estimated from the reference period 1961-1990 [20]. In order to provide the scientist with reliable data, the CRU carries out permanent updates. The work of Mitchell et al., (2005) [20] and Harris et al., (2014) [21] provide further details on this update. In our work, we used CRUTS2.1 from the rainfall variable, which is the enhanced version of CRUTS2.0 [20]. This is the data covering the continental surface on a global scale on a $0.5^{\circ} \times 0.5^{\circ}$ grid. In this study, these data were considered on a window covering West and Equatorial Africa. This can permit us to present our area study and Gulf of Guinea region.

\subsubsection{Re-analyzes Data (Era Interim)}

In recent years, several improved global atmospheric reanalysis data of the satellite period has been produced since 1979, allowing new applications of offline terrestrial surface simulations [22]. These include the Era Interim reanalysis of European Center for Medium-Range Weather Forecasts [23], and the retrospective analysis of the modern era of the National Aeronautics and Space Administration (NASA) for research and applications [24]. The work of Simmons et al., (2010) [25] has demonstrated the quality of Era Interim's near surface fields by comparing them with single observation climate data records. The products are 
intertwined with corrected models and supplemented by the following observations: Relative humidity $(\mathrm{Rh})$, wind $(\mathrm{u}, \mathrm{v})$, Temperature $(\mathrm{Ta})$, Specific humidity (q), Pressure $(\mathrm{Pa})$ etc. They have a resolution of $0.75^{\circ} \times 0.75^{\circ}$. The data we use in this work are monthly data JJASO (June-October) season with four times ( $00 \mathrm{~h}$, $06 \mathrm{~h}, 12 \mathrm{~h}, 18 \mathrm{~h}$ ) of observation and cover a 30 years period (1981-2010). Otherwise, an extension from 1979 to 1989 is currently available. The work of Berrisford et al., (2009) [26] detailed description of archived Era Interim products.

These data are part of the rainfall dynamics study which consists of calculating in lower level $(1000 \mathrm{hPa}-850 \mathrm{hPa}$ ): Precipitable water (Equation (1)), Moisture flow divergence (Equation (2)) and Moisture flow transport (Equation (3)) for rainfall analysis purposes.

\subsection{Methods}

The methodology adopted is the following: the first section deals with the mean seasonal cycle Guinea's rainfall. We focus in on each geophysical region of Guinea to carry out intra-regional studies to see the rainfall evolution in each station. The second section contains the monthly rainfall contributions (\%) analysis of the stations in each region considered. This makes it possible to identify among the twelve synoptic stations those that observe country's rainfall maxima and minima. That study also makes it possible to determine months during which these rainfall maxima or minima are recorded in Guinea and particularly in Conakry (LG).

Considering the two sus-mentioned, we consider the JJASO season third section, we focus on precipitable water vapor (Pwv) during the JJASO season. Several studies have been done to determine the water vapor amount on a global scale using measurements by satellite-based instruments such as POLDER and MODIS for the solar radiation reflected by the earth's surface [27]. It is given in the form of a thickness or surface mass of liquid water $\left(1 \mathrm{~mm}=1 \mathrm{~kg} \cdot \mathrm{m}^{-2}\right.$ of water). It can be converted in a liquid water mass whose density is assumed to be 1 , then becomes the water level expressed in same unit order $\left(\mathrm{kg} \cdot \mathrm{m}^{-2}\right)$. Its distribution in the troposphere and its variability are still poorly investigated [29], but this work will estimate it. The precipitable water varies between a few millimeter for the polar regions and more than $50 \mathrm{~mm}$ for the tropical regions [28]. It is calculated integrating the specific humidity on atmosphere vertical column by the equation below (Equation (1)). In our study, we calculate it in the lower level $(1000 \mathrm{hPa}-850 \mathrm{hPa})$, because the precipitable water maximum mark the maximum of potential rains, namely the location of the Inter-Tropical Convection Zone (ITCZ), and vice versa. The water vapor distribution results from the equilibrium between the sources (surface evaporation and evapo-transpiration) and wells (rainfall and clouds) as well as transport between them [9]. These elements are related to the atmospheric water cycle. The precipitable water permits to represent the water level (expressed in $\mathrm{mm}$ ). It is a very useful tool for assessing the precipitating potential of fronts and convective triggers (showers and thun- 
derstorms). Naturally, the more the air is humid, the higher is the precipitable water. In addition, the spatial distribution and seasonal evolution of precipitable water and rainfall are highly correlated [30], which is why Pwv enters in the study of the rainfall dynamics. They appear to be a threshold relationship between the two variables [31], with low or high rainfall amount corresponding to those of Pwv.

$$
\mathrm{PWV}=\frac{1}{g} \int_{P_{\text {top }}}^{P_{\text {surf }}} q \mathrm{~d} p
$$

where:

Pwv is Precipitable Water Vapor $\left[\mathrm{kg} \cdot \mathrm{m}^{-2}\right]$ and $P_{\text {surf }}$ is pressure at the lower level $[1000 \mathrm{hPa}]$.

$P_{\text {top }}$ is the pressure at the upper level limit of the lower level [850 hPa]. $q$ is specific humidity $[\mathrm{g} / \mathrm{kg}]$ et $g$ is gravity acceleration $\left[\mathrm{m} \cdot \mathrm{s}^{-2}\right]$.

The fourth section includes the moisture flow divergence calculated in the lower level $(1000 \mathrm{hPa}-850 \mathrm{hPa})$. This parameter permits to determine the area where the divergence flow (subsidence) or convergent (convection or advection) [32]. That is, it indicates where moisture tends to accumulate or become rare; the equation below (Equation (2)) is used for this purpose. When $Q$ values is negative, it is called convergent and divergent when it is positive. The divergence and convergence of the moisture flows can be interpreted respectively as source and wells of moisture [30].

$$
Q=\frac{1}{T} \int_{0}^{T} \frac{1}{g}\left(\int_{P_{b}}^{P_{t}} \nabla \cdot q u \mathrm{~d} p\right) \mathrm{d} t
$$

With:

$Q$ is divergence of the moisture flow $\left[\mathrm{kg} \cdot \mathrm{m}^{-2} \cdot \mathrm{s}^{-1}\right]$ and $q$ is specific humidity $[\mathrm{g} / \mathrm{kg}] . u$ is the zonal wind $\left[\mathrm{m} \cdot \mathrm{s}^{-1}\right], T$ is the mean time considered [jr] and $g$ acceleration of gravity $\left[\mathrm{m} \cdot \mathrm{s}^{-2}\right]$.

$P_{b}$ is ground pressure [1000 hPa] and $P_{\text {top }}$ is the pressure at upper limit of lower level $[850 \mathrm{hPa}]$ and $\nabla$ is the divergence.

In this fifth section, we focus on moisture flow transport (Equation (3)), calculated in the lower level and to indicate the flow direction. The moisture transport on the continent plays an important role in triggering convection [1]. It is one of the determining factors behind the deep convection formation areas on the continent during the rainy season onset, when soil evaporation is almost none. The work of Cadet et al., (1984) [34], provides further details on moisture flow transport.

$$
F_{v}=\frac{1}{T} \int_{0}^{T}-\frac{1}{g}\left(\int_{P_{b}}^{P_{t}} q u \mathrm{~d} p\right) \mathrm{d} t
$$

where:

$F_{V}$ is moisture flow transport $\left[\mathrm{mm} \cdot \mathrm{day}^{-1}\right]$ and $T$ is the average time considered [day]. $g$ is acceleration of gravity $\left[\mathrm{m} \cdot \mathrm{s}^{-2}\right] . P_{b}$ is ground pressure $\left[1000 \mathrm{hPa}\right.$ ] et $P_{\text {to }}$ is the pressure at upper limit of lower level [ $850 \mathrm{hPa}$ ]. $q$ is specific humidity $[\mathrm{g} / \mathrm{kg}], u$ is zonal wind $\left[\mathrm{m} \cdot \mathrm{s}^{-1}\right]$. 


\section{Results}

\subsection{West Africa Climatological Rainfall with the CRU Data}

The annual rainfall climatology over the period 1981-2010 in West Africa shown in Figure 4 highlights two regions with high rainfall. The first region is the Roberts FIR where our study area is located (Republic of Guinea) and the second is the Gulf of Guinea. We note that the annual rainfall in these areas varies between $3000 \mathrm{~mm} /$ year and $4500 \mathrm{~mm} /$ year. Regarding the Roberts FIR region, Liberia and Sierra Leone have a high rainfall than Guinea. However, despite the difference between climatological periods used, our results are in perfect harmony with work of (Manetsa et al., 2011) [10].

\subsection{Guinea Climatological Rainfall}

In FIR Roberts area, by a focus on the Republic of Guinea, climatological rainfall data over period 1981-2010 indicate that maxima rang between $3000 \mathrm{~mm} /$ year and $4500 \mathrm{~mm}$ /year. Among the 12 synoptic stations of Guinea, Figure 5 highlights Conakry and Macenta stations which record the highest rainfall in the country. These results confirm the provided information by the National Meteorological Service and monthly climatological tables.

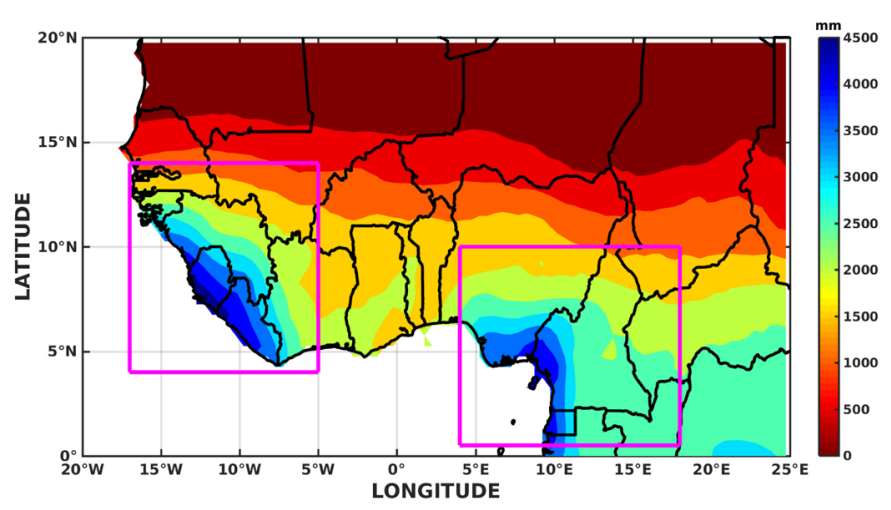

Figure 4. Average annual rainfall in West Africa regions (CRU, 1981-2010). The regions delineated in magenta represent the areas where rainfall maxima are observed.

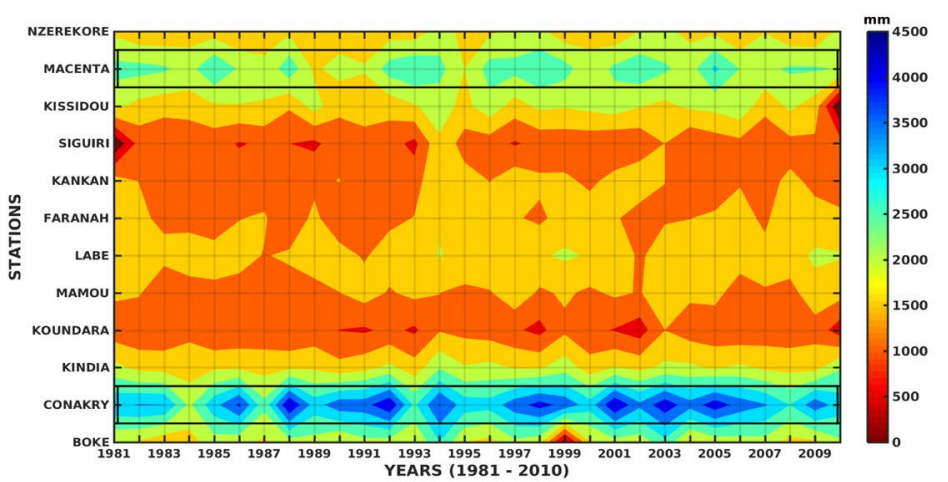

Figure 5. Total annual rainfall of the twelve (12) synoptic of Guinea during 1981-2010. The $\mathrm{x}$-axis and the $\mathrm{y}$-axis represent years and stations respectively. The black framed parts show areas with maximum rainfall. 


\subsection{Mean Seasonal Cycle of Rainfall in Guinea}

This section shows the mean seasonal cycle of rainfall in each Guinea's geophysical region (Figure 6). The mean seasonal cycle study of rainfall permits to identify the onset and offset of the rainy season. It also helps to understand the rainfall regime of each region through their stations.

In LG, Figure 6(a) presents a unimodal regime in these three (3) synoptic stations with a common peak in August. It also shows that the Conakry rainfall regime is different from those of the stations of its region (Kindia, Boke). This Conakry station has two exceptional rainfall peaks in July and August with 1050 $\mathrm{mm} / \mathrm{month}$ and $1100 \mathrm{~mm} / \mathrm{month}$ respectively. Figure 6(a) also indicates that the largest amount of rainfall in Conakry is recorded between June to September. The mean seasonal cycles of Boke and Kindia show similarity in the regime although the Boke rainfall exceeds that of Kindia from July to September. The peaks observed in August in Boke and Kindia are respectively $550 \mathrm{~mm} / \mathrm{month}$ and $500 \mathrm{~mm} / \mathrm{month}$. It should also be reminded that in LG, rainfall starts in April at Kindia, in May at Conakry and Boke, and end in the same month (November).

In Fouta Djallon region (MG), the Figure 6(b) presents a unimodal cycle in its stations namely: Koundara, Labe and Mamou. It also shows a similarity of regime in their evolutions during all the period with a peak in August, but it is in Mamou that the rainfall peak is observed ( $400 \mathrm{~mm} / \mathrm{month})$. The rainfall starts in April and ends in November at the same time in these three stations. The station with largest rainfall amount is of the Mamou with $400 \mathrm{~mm} / \mathrm{month}$ and the least watered is that of Koundara with $350 \mathrm{~mm} /$ month where the rainfall season starts in May.

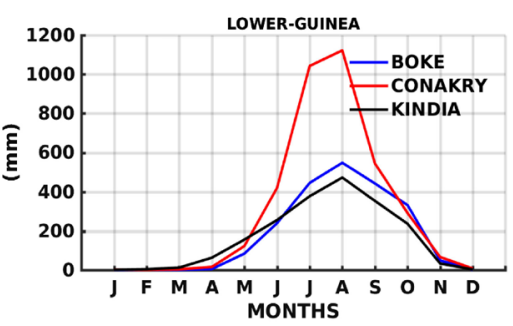

(a)

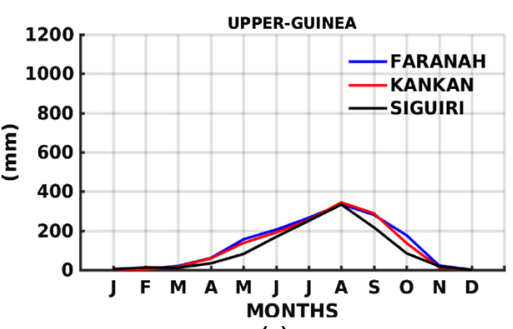

(c)

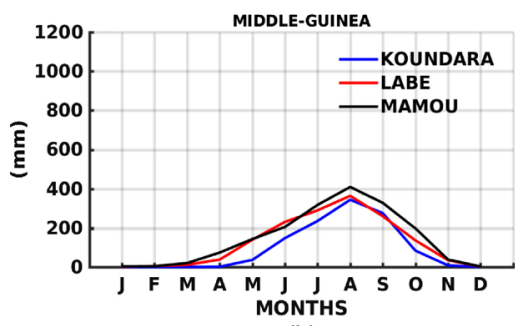

(b)

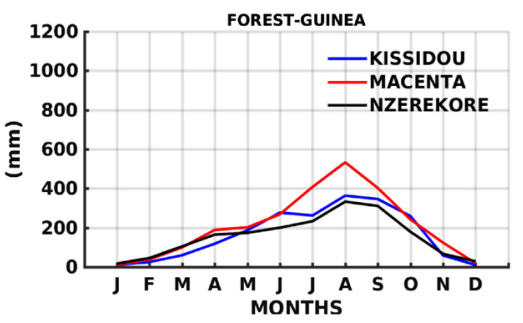

(d)

Figure 6. Mean seasonal cycle of rainfall by Guinea synoptic stations during 1981-2010 period. (a) Lower-Guinea (Boke, Conakry, Kindia); (b) Middle-Guinea (Koundara, Labe, Mamou); (c) Upper-Guinea (Faranah, Kankan, Siguiri); (d) Forest-Guinea (Kissidou, Macenta, Nzerekore). The $\mathrm{x}$-axis and $\mathrm{y}$-axis are respectively the months and rainfall heights. 
In UG in the semi-arid region of Guinea, composed of Faranah, Kankan and Siguiri, Figure 6(c) presents a unimodal rainfall regime. The rainfall peaks of these stations are observed in August with rainfall amount of $350 \mathrm{~mm} / \mathrm{month}$. The rainfall starts in this region in April and ends in November in each station. Compared to other regions, it the region where less rainfall total is recorded, this is due to its geographical position and the late onset as well as the rapid withdrawal of ITCZ. The Siguiri station, located further in the north records less rainfall and the wettest stations are Faranah and Kankan.

The stations of FG (Figure 6(d)) also exhibit a unimodal regime similar to those of other regions (UG, MG and UG) with a peak in August. In this region, the rainfall peak is observed in Macenta at $550 \mathrm{~mm} /$ month, followed by Kissidou with $390 \mathrm{~mm} / \mathrm{month}$. The rainfall starts very early in February and ends late in November. This situation is explained by the very early ITCZ position in the southern Guinea part and its late withdraw. Kissidou and Nzerekore stations have two remarkable rainfall peaks, in August and the other in September respectively. Nzerekore station, meanwhile, is the with recording less rainfall amount $370 \mathrm{~mm} / \mathrm{month}$.

\subsection{Monthly Rainfall Contribution of Guinea's Synoptic Stations}

In this section, we show the monthly rainfall contribution of the stations in each Guinea geophysical region (Figure 7).

In the coastal region (LG), at the season start (April-May), Figure 7(a) shows that Kindia station (in yellow) receives more rainfall compared to Conakry and Boke. Conakry's station (in green) has the higher contribution than Kindia and Boke in June, July, August and September. However, two exceptional peaks are

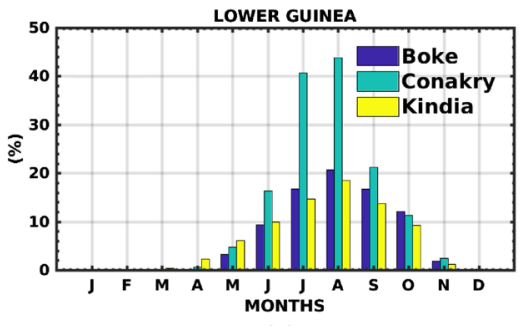

(a)

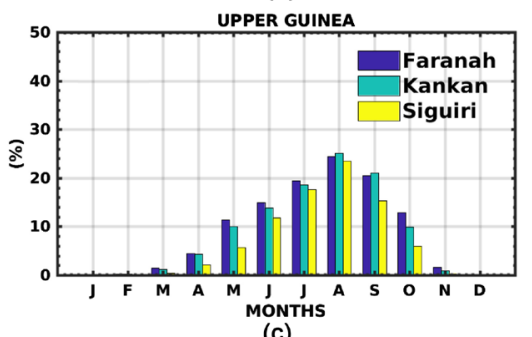

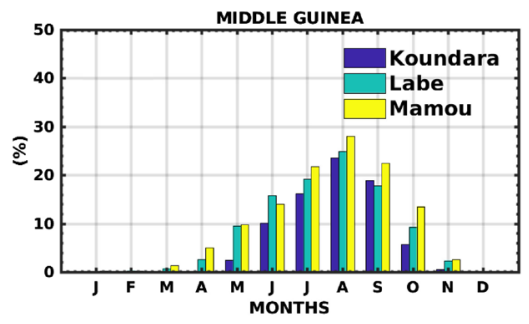

(b)

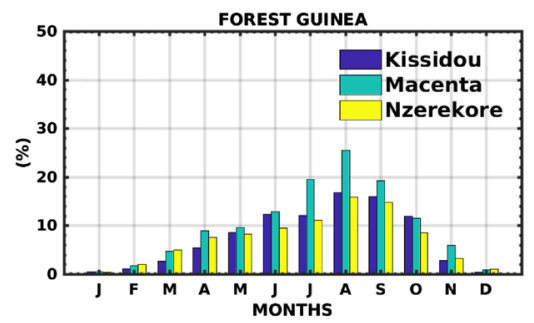

(d)

Figure 7. Monthly rainfall contribution of each station into its corresponding region. (a) Lower-Guinea (Boke, Conakry, Kindia); (b) Middle-Guinea (Koundara, Labe, Mamou); (c) Upper-Guinea (Faranah, Kankan, Siguiri); (d) Forest-Guinea (Kissidou, Macenta, Nzerekore). 
observed respectively in July and August. Boke's station (in blue) has a greater rainfall contribution than Conakry in July, August, September and October. It is noted that Conakry rainfall high contribution could be explained not only by the coastal influence but also by orography (Kakoulima Mountain Range).

In Fouta Djallon region (Figure 7(b)), in the begining season (March-April) and in the full season (July-Octobre), Mamou's station (in yellow) has higher rainfall contributions than other stations in this region. However, Labe (in green) and Mamou stations are the wettest in the MG region. Koundara's has a less contributions (in blue). However, they have a similar rainfall variability in all seasons with substantially similar contributions. This similar rainfall pattern is due to the influence Fouta Djallon massifs on these three stations.

The UG region is considered as the arid Guinea area due to its hot and dry climate like in the Sahel. Figure 7(c) indicates that different stations in this region have a similar regime from the season start and the season end. The rainfall contributions of Faranah station (in blue) are slightly higher than the others during May to November. Kankan contribution (in green) is higher only during August and September. In Siguiri station (in red), the rainfall contribution of this station is less important in region.

The Guinea forest region (FG) is the area where it can rain during all the year. Figure 7 (d) shows that Macenta's station (green) has the strongest rainfall contributions as compared to other stations of its region. This is consistent with [17] results, which showed rainy days to be higher than Macenta and FG compared to other parts of the country. After this station, that of Kissidou (blue) take the second place whose rainfall exceeds that of Nzerekore (yellow). However, the rainfall contributions of Nzerekore station are less significant compared to the others. Macenta station case is explained by the existence of classified forests of Ziama and certain orographic areas.

\subsection{Precipitable Water over Guinea}

This section concerns the precipitable water amount calculated in the lower level (Figure 8). Tropospheric water vapor enters the water cycle and comes mainly from evaporation. It is a major component in the clouds formation and rainfall to predict weather on a large scale. The precipitable water is all water vapor contained in the air column that can precipitate, its related to the specific humidity. It is also important in meteorology, evolution in time and space with the atmosphere movement.

In Guinea, during June (Figure 8(a)), rainfall amount ranges between 30 $\mathrm{kg} \cdot \mathrm{m}^{-2}$ to $40 \mathrm{~kg} \cdot \mathrm{m}^{-2}$ at the coast (Conakry) and south (Macenta, Nzerekore) showing the rainfall onset in these areas. In Koundara (MG) north and Siguiri (UG), the weak gradients are observed with values ranging between $10 \mathrm{~kg} \cdot \mathrm{m}^{-2}$ and $20 \mathrm{~kg} \cdot \mathrm{m}^{-2}$. The rainfall onset corresponds to the ITCZ position over Guinea accompanied by a strong activity of the stormy convective systems.

In July (Figure 8(b)), August (Figure 8(c)) and September (Figure 8(d)), the gradients notably increase over Conakry except during October (Figure 8(e)) 


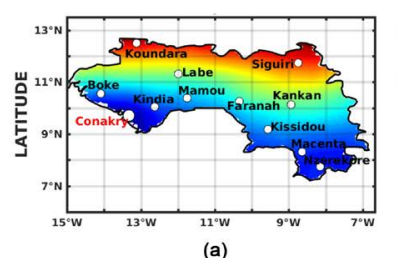

(a)

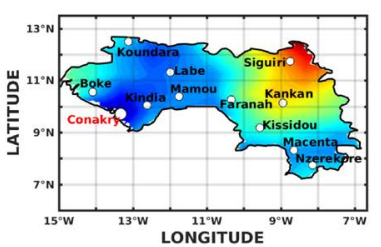

(d)

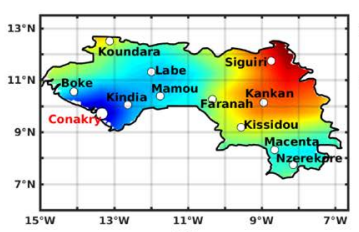

(b)

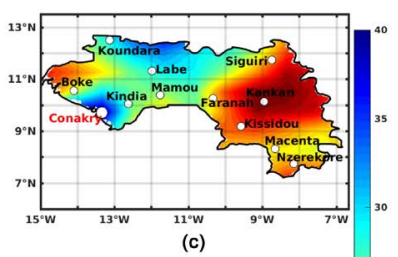

(c)

Figure 8. Precipitable water calculated in lower level $(1000 \mathrm{hPa}-850 \mathrm{hPa})$ over Guinea from 1981-2010 during the JJASO season, expressed in $\mathrm{kg} \cdot \mathrm{m}^{-2}$. The white dots are the twelve synoptic stations of Guinea. (a) June; (b) July; (c) August; (d) September; (e) October.

where the strong gradients are further in the south and are not interest this station. This situation on Conakry during July, August and September months is in perfect agreement with what has been shown on the monthly rainfall contribution (Figure 7).

During September (Figure 8(d)), the maximum rainfall is particularly found in the coastal area and Fouta Djallon reliefs, this is due to local convective systems implied by orographic origin. This confirm during the rainy season, rainfall maxima are recorded in the coastline and around Conakry.

In October (Figure 8(e)), the maximum rainfall is observed in the forest region (Macenta, Nzerekore) corresponding to the withdrawal of the ITCZ. It is the region with largest rainy days number [17], due to the late withdrawal of the ITCZ. All of these analyzes on precipitable water explain a favorable structure for the cloud.

\subsection{Moisture Flow Divergence over Guinea}

This part is devoted to the moisture flow divergence over the Guinea it indicates where the humidity contribution is important on the territory (Figure 9).

In June (Figure 9(a)), strong gradients of moisture convergence (negative divergence or advection) are observed in the southwest around Mount Kakoulima, especially between Kindia and around. In the same month, other strong gradients are visible in the north of Guinea around Fouta Djallon massifs. This explains the existence of deep convection in these region in June, characterizing the onset monsoon in Guinea with the ITCZ position. At the extern eastern of Guinea (UG) and the north-west (LG), a subsidence (positive divergence) is observed.

In the monsoon season, from July (Figure 9(b)) to August (Figure 9(c)), the existence of a moisture convergence band in the coast (around Conakry) with a very strong gradient identified, this is associated with the orographic effect and 


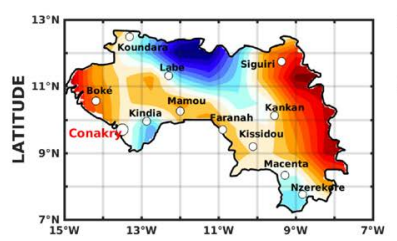

(a)

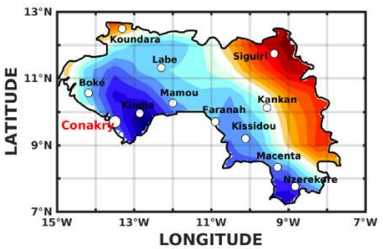

(d)

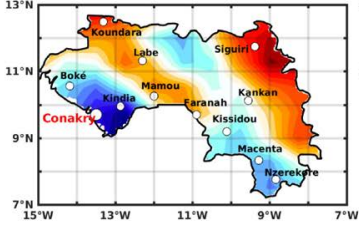

(b)

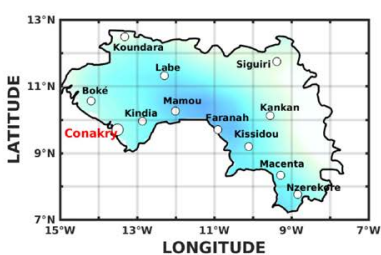

(e)

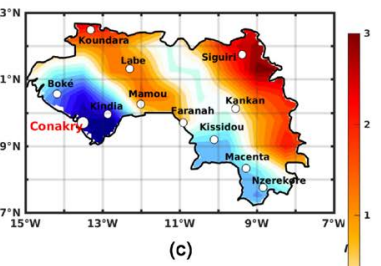

Figure 9. Moisture flow divergence calculated in the lower level $(1000 \mathrm{hPa}-850 \mathrm{hPa})$ over Guinea from 1981-2010 during the JJASO season, expressed in $\mathrm{kg} \cdot \mathrm{m}^{-2} \cdot \mathrm{s}^{-1}$. The white dots represents the twelve synoptic stations of Guinea. (a) June; (b) July; (c) August; (d) September; (e) October.

the oceanic proximity. This is consistent with the mean seasonal cycle (Figure $6(\mathrm{a})$ ), monthly rainfall contribution (Figure $7(\mathrm{a})$ ) and precipitable water (Figure 8(b) and Figure 8(c)). There is also a strong moisture convergence gradient in the north upstream of the Fouta Djallon massifs. This strip continues to the southwest around Kissidou, Macenta and Nzerekore where the Simandou Massifs and Mount Nimba are located with deep convection areas. These results are in agreement with those the work of Meynadier et al., (2010) [30] which states that over the ocean, moisture flow are essentially divergence near of high pressure (they export humidity) and converge the ITCZ position (the import humidity).

At the end of the season, from September (Figure 9(d)) to October (Figure 9(e)), a decrease in moisture gradient is observed towards the south, at the coast and around the Fouta Djallon massifs. This movement is related to the ITCZ position, which corresponds in this case to its withdrawal, ending the monsoon activities in Guinea.

\subsection{Moisture Flow Transport over Guinea}

This section highlights the moisture flow transport in the lower level throughout the season JJASO (Figure 10). Indeed, water vapor evaporated over the Atlantic Ocean is transported in lower level by the monsoon flow (South-West) which penetrates more clearly on the African continent (West). It then directly feeds deep convection in ITCZ, which is starting to generate rainfall in the southern part of West Africa [30].

In Guinea, the coastal region (LG) and Fouta Djallon massifs (MG) are areas concerned by the western flow maximum, highlighting the Guinea's rainfall distribution by region. In lower atmospheric layers, monsoon flow (southwest) is the dominant support for moisture transport over the continent (West Africa). 


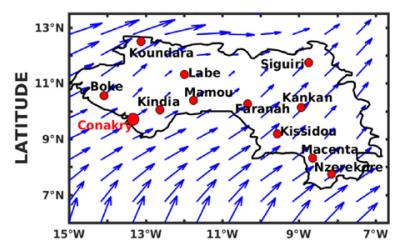

(a)

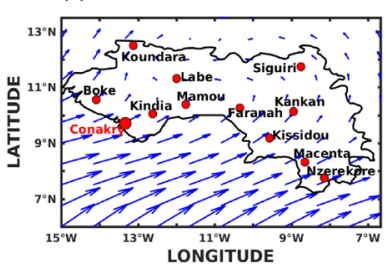

(d)

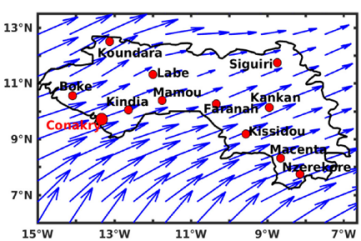

(b)

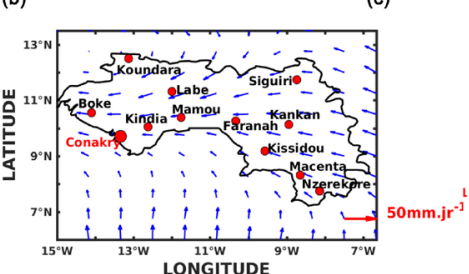

(e)

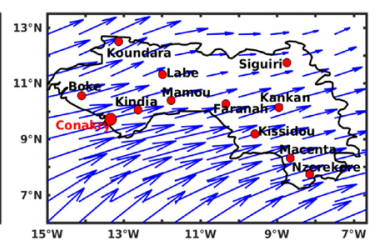

(c)

Figure 10. Moisture flow transport on Guinea calculated in lower level $(1000 \mathrm{hPa}-850$ $\mathrm{hPa}$ ) from 1981-2010 during the JJASO season, expressed in $\mathrm{kg} \cdot \mathrm{m}^{-2} \cdot \mathrm{s}^{-1}$. The red dots are the twelve synoptic stations of Guinea. (a) June; (b) July; (c) August; (d) September; (e) October.

This flow direction is almost that of the wind but its intensity also depends on the humidity in lower level (exceeding $50 \mathrm{~kg} \cdot \mathrm{m}^{-2} \cdot \mathrm{s}^{-1}$ ).

In June (Figure 10(a)) the moisture flow transport is from west, south and south-west, so a homogeneous distribution of moisture flow across the country. However, in July (Figure 10(b)) and August (Figure 10(c)), moistures flow is dominated especially by those from west corresponding to the rainfall maxima recorded at the coast (Conakry). This confirms what the average rainfall cycle showed (Figure 6(a)), monthly rainfall contributions (Figure 7(a)), precipitable water (Figure 8(b) and Figure 8(c)) and moisture flow divergence (Figure 9(b) and Figure 9(c)). In September (Figure 10(d)) and October (Figure 10(e)), the flows transports are respectively southwest and south, and therefore very variable. In the other hand, on the continent, the moisture flows are East flow, thus dominated by altitude jets: mainly East African Jet [33], this is observed on a small-scale on Guinea in the month of October.

\section{Discussions and Conclusions}

\subsection{Discussions}

The analysis of rainfall climatology on West Africa over the period 1981-2010 are consistent with the work of Manetsa et al., (2011) [10] which make over the 1951-2002. Our results on the mean seasonal cycle of rainfall and the monthly rainfall contributions in the forest region with Macenta station are in agreement with the work of Beavogui et al., (2011) [17]. The analysis of the moisture flow divergence shows strong gradients of moisture convergence in the orographic areas. These confirm the studies of Sall et al., (1999) [13] and Mathon et al., (2001) [14] which showed that in Africa, the main mountainous areas generally correspond to the cloud cover maximum. They are also consistent with the work of Meynadier et al., (2010) [30] which were strong convergence gradients are 
observed representing moisture wells that are favorable to convection and rainfall.

The strong gradients of moisture convergence observed in Guinea's forest area are in agreement with the work of GarciaCarreras et al., (2011) [36]. These findings state that the area with moisture convergence created by the heterogeneities between crops and forests implies favorable conditions for the convection initiation during the afternoon. However, with the moisture flow transport found in our study, at small-scale on Guinea in October, is in agreement with the works of Long et al., (2000) [35]. These works show that on the continent's moistures flow are east fow, dominated by East African Jet.

We believe that this analysis method could be useful for other similar areas in West Africa or anywhere in the work.

\subsection{Conclusions}

The analysis of the mean rainfall seasonal cycle of Guinea shows unimodal variability in geophysical regions in general and particularly in the stations. The rainfall onset in April and offset in November in the LB, MG and the UG. In FG region rainfall onset very early in February and ends lately in November. This difference is due to the geographical position of each region in relation to ITCZ movement. Southern Guinea is the region with a long rainy period 10 months, e.g. February-November. Therefore, the presence of the Ziama's classified forests, mountain ranges like Nimba Mountains and Simandou contribute is an important aspect. In Conakry station, two exceptional peaks are exhibited, one in July and the other in August. We have also identified in descending order the wettest synoptic stations of Guinea as follows: Conakry, Macenta, Mamou and Faranah.

The monthly rainfall contribution study in the different synoptic stations of Guinea permits to indicate the spatial distribution on the monthly scales. The finding of this study showed that Guinea's rainfall maxima are observed in the coastal area (LG) more specifically in Conakry ranging between 3300 and 4500 $\mathrm{mm}$ /year with two peaks in July and August. In LG, Kindia station recorded an important rainfall contribution at the beginning of the season compared to Conakry and Boke. The Conakry station, shows a rainfall contribution higher than Kindia and Boke in June, July, August and September where two main peaks are observed (July and August). In Fouta Djallon region (MG), at the start (March, April, May) and in the full season (July, August, September), the Mamou rainfall contribution is higher than in other stations in his region. On the other hand, Koundara contribution is lower than those of other MG stations. In UG, Faranah's monthly rainfall contributions are slightly higher than the other stations from May to July and from October to November. In southern Guinea (FG), Macenta station has a higher contribution rainfall than other stations in its region. However, Kissidou station comes in second position whose rainfall exceeds that of Nzerekore. 
The precipitable water analysis in the lower level, shows that the maximum values are observed over coast (Conakry) and in south (Macenta, Nzerekore) almost during JJAS season. In October, they are observed south, corresponding to the ITCZ withdrawal indicating the appearance of very pronounced humidity in these areas favorable to deep convection. As a result, we are in favorable conditions for initiation of convection and rainfall, illustrating that atmospheric moisture is driving monsoon rainfall in the tropics [30].

From the moisture flow divergence, at the beginning of the season (June), the strong gradients of moisture convergence are observed in Fouta Djallon massifs, favorable to deep convection. Between July and August, the appearance of a strong convergence gradient of moisture over Conakry and about is also noticed, which is associated with the orographic effect (foehn) and oceanic influence. This season also coincides with the maximum precipitable water and rainfall observed at the coast (Conakry). During the end of season, we also observed a very marked moisture convergence gradient in orographic areas of Guinea: at Fouta Djallon and in the forest.

The moisture flow transport has a very pronounced variability as a function to the seasons. At onset season, the moisture flow observed are very variable between west, south and southwest. But during the monsoon, they are dominated especially by those of west and south-west confirming the rains maxima recorded in Conakry.

\section{Acknowledgements}

This study was funded by SCAC (Service de Cooperation et d'Action Culturelle de l'Ambassade de France en Guinée) and AFIMEQG (Afrique pour l'Innovation, Mobilité, Echange, Globalisation et Qualité) of European Union (EU) which are institutions of mobility program and cooperation in the field of Higher Education. The authors present their warm thanks to these institutions, whose scholarship awarded to Ibrahima Kalil Kante permits the achievement of this paper. In addition, the authors would like also to thank the NMS (Nationale Meteorology Service) of Guinea and University Gamal Abdel Nasser of Conakry, but also the LPAOSF (Laboratoire de physique de l'Atmosphère et de l'Océan Siméon Fongang) in Senegal who welcomed Ibrahima Kalil Kante in the framework of his Ph.D studie.

\section{Conflicts of Interest}

The authors declare on conflicts of interest regarding the publication of this paper.

\section{References}

[1] Dione, C., Lothon, M., Badiane, D., Campistron, B., Couvreux, F., Guichard, F. and Sall, S.M. (2013) Phenomenology of Sahelian Convection Observed in Niamey during the Early Monsoon. Quarterly Journal of the Royal Meteorological Society, 140, 500-516. https://doi.org/10.1002/qj.2149 
[2] Thorncroft, C.D. (1995) An Idealized Study of African Easterly Waves. III: More Realistic Basic States. Quarterly Journal of the Royal Meteorological Society, 121, 1589-1614. https://doi.org/10.1002/qj.49712152706

[3] Houze, R.A. (1993) Cloud Dynamics. Academic Press, Cambridge, 573 p.

[4] Quaas, J. (2012) Evaluating the Critical Relative Humidity as a Measure of Subgrid-Scale Variability of Humidity in General Circulation Model Cloud Cover Parameterizations Using Satellite Data. Journal of Geophysical Research: Atmospheres, 117, D09208. https://doi.org/10.1029/2012JD017495

[5] Findell, K.L. and Eltahir, A.B. (2003) Atmospheric Controls on Soil MoistureBoundary Layer Interactions. Part I: Framework Development. Journal of Hydrometeorology, 4, 552-569. https://doi.org/10.1175/1525-7541(2003)004<0552:ACOSML >2.0.CO;2

[6] Taylor, C.M. and Ellis, R.J. (2006) Satellite Detection of Soil Moisture Impacts on Convection at the Mesoscale. Geophysical Research Letters, 33, L03404. https://doi.org/10.1029/2005GL025252

[7] Laurent, H., D’Amato, N. and Lebel, T. (1998) How Important Is the Contribution of the Mesoscale Convective Complexes to the Sahelian Rainfall. Physics and Chemistry of the Earth, 23, 629-633. https://doi.org/10.1016/S0079-1946(98)00099-8

[8] Laing, A.G., Fritsch, J.M. and Negri, A.J. (1999) Contribution of Mesoscale Convective Complexes to Rainfall in Sahelian Africa: Estimates from Geostationary Infrared and Passive Microwave Data. Journal of Applied Meteorology, 38, 957-964. https://doi.org/10.1175/1520-0450(1999)038<0957:COMCCT>2.0.CO;2

[9] Bielli, S. and Roca, R. (2010) Scale Decomposition of Atmospheric Water Budget over West Africa during the Monsoon 2006 from NCEP/GFS Analyses. Climate Dynamics, 35, 143-157. https://doi.org/10.1007/s00382-009-0597-5

[10] Djoufack-Manetsa, V. (2011) Étude multi-échelles des précipitations et du couvert végétal au Cameroun: Analyses spatiales, tendances temporelles, facteurs climatiques et anthropiques de variabilité du NDVI. Doctoral Dissertation, Université de Bourgogne; Université de Yaoundé, Yaoundé.

[11] Stock, R. (2012) Africa South of the Sahara: A Geographical Interpretation. Guilford Press, New York.

[12] Bouali, L. (2009) Prévisibilité et prévision statistico-dynamique des saisons des pluies associées à la mousson ouest africaine à partir d'ensembles multi-modèles. Doctoral Dissertation, Dijon.

[13] Sall, S.M., Viltard, A. and Sauvageot, H. (2007) Rainfall Distribution over the Fouta Djallon-Guinea. Atmospheric Research, 86, 149-161. https://doi.org/10.1016/j.atmosres.2007.03.008

[14] Mathon, V. and Laurent, H. (2001) Life Cycle of the Sahelian Mesoscale Convective Cloud Systems. Quarterly Journal of the Royal Meteorological Society, 127, 377406. https://doi.org/10.1002/qj.49712757208

[15] Kante, I.K., Sall, S.M., Badiane, D. and Diouf, I. (2019) Seasonal Variability of Rainfall and Thunderstorms in Guinea over the Period 1981 to 2010. African Journal of Environment Science and Technology, 13, 324-341.

https://doi.org/10.5897/AJEST2019.2684 https://academicjournals.org/journal/AJEST/article-full-text-pdf/A1BB5D361633

[16] Frenken, K. (2005) Irrigation in Africa in Figures: AQUASTAT Survey 2005 (Vol. 29). Food \& Agriculture Org.

[17] Sall, S.M., Viltard, A. and Sauvageot, H. (2007) Rainfall Distribution over the Fouta 
Djallon-Guinea. Atmospheric Research, 86, 149-161. https://doi.org/10.1016/j.atmosres.2007.03.008

[18] Béavogui, K., Badiane, D., Sall, S.M. and Diaby, I. (2011) Approche climatologique des phénomènes pluvio-orageux en Guinée. Journal des Sciences Pour P Ingénieur, 13, 71-77.

[19] Jenkins, G.S., Pratt, A.S. and Heymsfield, A. (2008) Possible Linkages between Saharan Dust and Tropical Cyclone Rain Band Invigoration in the Eastern Atlantic during NAMMA-06. Geophysical Research Letters, 35, L08815. https://doi.org/10.1029/2008GL034072

[20] Mitchell, T.D. and Jones, P.D. (2005) An Improved Method of Constructing a Database of Monthly Climate Observations and Associated High-Resolution Grids. International Journal of Climatology: A Journal of the Royal Meteorological Society, 25, 693-712. https://doi.org/10.1002/joc.1181

[21] Harris, I.P.D.J., Jones, P.D., Osborn, T.J. and Lister, D.H. (2014) Updated HighResolution Grids of Monthly Climatic Observations: The CRU TS3.10 Dataset. International Journal of Climatology, 34, 623-642. https://doi.org/10.1002/joc.3711

[22] Balsamo, G., Albergel, C., Beljaars, A., Boussetta, S., Brun, E., Cloke, H., De Rosnay, P., et al. (2015) Era Interim/Land: A Global Land Surface Reanalysis Data Set. Hydrology and Earth System Sciences, 19, 389-407. https://doi.org/10.5194/hess-19-389-2015

[23] Dee, D.P., Uppala, S.M., Simmons, A.J., Berrisford, P., Poli, P., Kobayashi, S., Andrae, U., Balmaseda, M.A., Balsamo, G., Bauer, P., Bechtold, P., Beljaars, A., van de Berg, L., Bidlot, J., Bormann, N., Delsol, C., Dragani, R., Fuentes, M., Geer, A.J., Haimberger, L., Healy, S.B., Hersbach, H., Hólm, E.V., Isaksen, L., Kallberg, P., Köhler, M., Matricardi, M., McNally, A.P., Monge-Sanz, B.M., Morcrette, J.-J., Park, B.K., Peubey, C., de Rosnay, P., Tavolato, C., Thépaut, J.-N. and Vitart, F. (2011) The Era Interim Reanalysis: Configuration and Performance of the Data Assimilation System. Quarterly Journal of the Royal Meteorological Society, 137, 553-597. https://doi.org/10.1002/qj.828

[24] Rienecker, M.M., Suarez, M.J., Gelaro, R., Todling, R., Julio, B., Liu, E., Bosilovich, M.G., Schubert, S.D., Takacs, L., Kim, G.K., Bloom, S., Chen, J., Collins, D., Conaty, A., da Silva, A., Gu, W., Joiner, J., Koster, R.D., Lucchesi, R., Molod, A., Owens, T., Pawson, S., Pegion, P., Redder, C.R., Reichle, R., Robertson, F.R., Ruddick, A.G., Sienkiewicz, M. and Woollen, J. (2011) MERRA-NASA's Modern-Era Retrospective Analysis for Research and Applications. Journal of Climate, 24, 3624-3648. https://doi.org/10.1175/JCLI-D-11-00015.1

[25] Simmons, A.J., Willett, K.M., Jones, P.D., Thorne, P.W. and Dee, D.P. (2010) LowFrequency Variations in Surface Atmospheric Humidity, Temperature, and Precipitation: Inferences from Reanalyses and Monthly Gridded Observational Data Sets. Journal of Geophysical Research: Atmospheres, 115, D01110. https://doi.org/10.1029/2009JD012442

[26] Berrisford, P., Dee, D.P.K.F., Fielding, K., Fuentes, M., Kallberg, P., Kobayashi, S. and Uppala, S. (2009) The Era Interim Archive. ERA Report Series, No. 1, 1-16.

[27] Vesperini, M., Breon, F.M. and Tanre, D. (1999) Atmospheric Water Vapor Content from Spaceborne POLDER Measurements. IEEE Transactions on Geoscience and Remote Sensing, 37, 1613-1619. https://doi.org/10.1109/36.763275

[28] Duvel, J.P., Basdevant, C., Bellenger, H., Reverdin, G., Vialard, J. and Vargas, A. (2009) The Aeroclipper: A New Device to Explore Convective Systems and Cyclones. Bulletin of the American Meteorological Society, 90, 63-71. https://doi.org/10.1175/2008BAMS2500.1 
[29] Chahine, M.T. (1992) The Hydrological Cycle and Its Influence on Climate. Nature, 359, 373-380. https://doi.org/10.1038/359373a0

[30] Meynadier, R. (2010) Analyse multi-échelle du cycle de l'eau dans la mousson africaine à l'aide d'observations GPS. Doctoral Dissertation, Université Pierre et Marie Curie-Paris VI, Paris.

[31] Bock, O., Bouin, M.N., Doerflinger, E., Collard, P., Masson, F., Meynadier, R., Nahmani, S., Koité, M., Gaptia Lawan Balawan, K., Didé, F., Ouedraogo, D., Pokperlaar, S., Ngamini, J.B., Lafore, J.P., Janicot, S., Guichard, F. and Nuret, M. (2008) The West African Monsoon Observed with Ground-Based GPS Receivers during AMMA. Journal of Geophysical Research, 113, D21105. https://doi.org/10.1029/2008JD010327

[32] Boudevillain, B., Argence, S., Claud, C., Ducrocq, V., Joly, B., Joly, A., Arbogast, P., et al. (2009) Projet Cyprim, Partie I: Cyclogenèses et précipitations intenses en région méditerranéenne: origines et caractéristiques. La Météorologie, 66, 18-28. https://doi.org/10.4267/2042/28828

[33] Koster, R.D., Dirmeyer, P.A., Guo, Z., Bonan, G., Chan, E., Cox, P., Liu, P., et al. (2004) Regions of Strong Coupling between Soil Moisture and Precipitation. Science, 305, 1138-1140. https://doi.org/10.1126/science.1100217

[34] Cadet, D.L. and Nnoli, N.O. (1987) Water Vapour Transport over Africa and the Atlantic Ocean during Summer 1979. Quarterly Journal of the Royal Meteorological Society, 113, 581-602. https://doi.org/10.1002/qj.49711347609

[35] Long, M., Entekhabi, D. and Nicholson, S.E. (2000) Interannual Variability in Rainfall, Water Vapor Flow, and Vertical Motion over West Africa. Journal of Climate, 13, 3827-3841. https://doi.org/10.1175/1520-0442(2000)013<3827:IVIRWV>2.0.CO;2

[36] GarciaCarreras, L. and Parker, D.J. (2011) How Does Local Tropical Deforestation affect Rainfall? Geophysical Research Letters, 38, L19802. https://doi.org/10.1029/2011GL049099 